\title{
EFFECT OF ADDING MARJORAM POWDER TO BROILER CHICKS DIET ON PERFORMANCE, BLOOD AND ANTIOXIDANT ENZYME ACTIVITY.
}

\author{
A. A. Abdel-Wahab \\ Poultry Production Department, Faculty of Agriculture, Fayoum University, 63514 Fayoum, Egypt. \\ *To whom all correspondence should be addressed. Email: aaa16@fayoum.edu.eg
}

(Received 5/11/2019, accepted 26/12/2019)

\section{SUMMARY}

\begin{abstract}
A ggregate of 180 Cobb broiler chicks were randomly assigned to 5 dietary groups, each group contain three replicates (12 chicks each) the experiment lasted 38 days. The first group fed on basal control diet without any additives, while, the rest fed on basal control diet supplemented with 1.0, 1.5, 2.0 and $2.5 \%$ marjoram powder (MP) respectively. The obtained results showed that dietary MP improved performance parameters of broilers especially with $1.5 \% \mathrm{MP}$, whereas causing significant increase in live body weight at 21 and 38 days of age, body weight gain, improving feed intake and feed conversion ratio at all periods than the control group and other treatments. Red and white blood cells, hemoglobin, alanine aminotransferase, aspartate aminotransferase, total protein and albumen were influenced by MP levels, but platelets, globulin and albumen to globulin ratio were not affected by treatments. Marjoram powder supplementation decreased serum cholesterol level, triglyceride and low density lipoproteins, but increasing high density lipoproteins and glutathione peroxidase activity compared to the control group. Overall, these data indicate that, supplementing MP into the broiler diets improved productive performance, physiological parameters, antioxidant enzyme activity (glutathione peroxidase) and lipid profiles especially with $1.5 \%$ MP.
\end{abstract}

Keywords: broilers nutrition, marjoram or oregano, performance, physiological parameters, plasma constituents, antioxidant enzyme activity.

\section{INTRODUCTION}

No suspicion that antibiotics in animal production performed an essential position as health and growth promoter. But, the cursive tendency is to seek for alternative to antibiotics that used in diets on account of audience apprehension from occurrence antibiotic-resistant bacteria and residues of antibiotic (Stanacev et al., 2011). Consequently, the poultry diets manufacture, uncover to mounting consumer stress to decrease the employ of antibiotic as growth promoters in poultry feeds, must be using natural feed additives as substitution (Botsoglou et al., 2004). Thus, for increase poultry output some investigators are surveying natural alternates to antibiotics, e.g., oregano essential oil, OEO (Adil et al., 2011 and Khan et al., 2012).

Additives derived from plants that called "phytogenic feed additives" using in poultry diets to increase production (Windisch et al., 2008). The major procedure of conduct for feed additives as growth promoters may be referred fundamentally to the fixation of food hygiene, moreover the useful effect on the gastrointestinal microbiota by commanding pathogens (Roth and Kirchgessner, 1998). Clostridium perfringens condensation decreased in faeces and the intestinal tract of chicks out of the whole breeding duration by using combination from essential oils such as thymol, eugenol, curcumin and piperin(Mitsch et al., 2004). Many food additives fundamentally using particularly or in collection in powder forms or essential oils in trade chick production such as rosemary, thyme, garlic, oregano, sage, chilli and black pepper (Puvaca et al., 2014).

The important medicinal and economical value for natural outputs comes from resolving numerous emerging health problems (Abdel-Daim et al., 2014). Moreover, Ghazalah and Ali (2008) showed that herbal and medicinal plants can raise the useful of food nutrients that may thereafter outcome increasing in body weight gain, great production averages and get better feed efficiency. 
A lot of strong ingredients can too be found in essential oils of the herbal and medicinal plants. In the same trend Mathlouth et al. (2012) reported that the essential oil of Origanum heracleoticum L (Syn.O. vulgare L) plant characterized by a rise phenolic satisfy (4.09\% thymol and $69.55 \%$ Carvacrol) and two monoterpene hydrocarbons, cymol and $\gamma$-terpinene (10.57 and 3.05\% of the whole oil, respectively). It is interesting, OEO ability act an anticoccidial influence versus Eimeria tenella (Giannenas et al., 2003), growth supporting belongings, antioxidant performance, offered strong antibacterial belongings versus cecal E. coli in chicks and progress chick immune restraint (Roofchaee et al., 2011). Food complementation by carvacrol and thymol increased execution, raised antioxidant enzymes efficiency, delay lipid oxidation, increased the action of digestive enzymes, and get bettered immune restraint of chicks (Hashemipour et al., 2013). Oregano essential oil has many natural components doing an alternate to antibiotics, hold strongly qualified for production characteristic and stimulatory trails on broilers digestion (Zhang et al., 2005). That countenance can increase the feed efficiency on account of favorable effects on the food digestibility (Hernandez et al., 2004) and antimicrobial actions (Dorman and Deans, 2000). Several studies showed that using OEO coming from (oregano origanum vulgare L.) in chick feeds increased body weight and feed consumed; but, the OEO doing on chick performance remains argumentative (Symeon et al., 2010). Thymol, carvacrol, $\rho$-cymene and $\gamma$-terpinene are the generality significant ingredients of OEO entangled in the effective advantages of oregano (Lee et al., 2004).

The main phenol preponderantly found in oregano is carvacrol (Kim et al., 2013). Quantities of carvacrol in hop marjoram (dittany of crete) about $70 \%$ and marjoram about $50 \%$ (Leon-Rodriguez et al., 2008). Some researches in vivo and in vitro showed various bioactivity of carvacrol alimentary, inclusive antispasmodic, antioxidant, anti-inflammatory, antiseptic, antibacterial, antiviral, growth stimulus, antifungal, expectorant, immunomodulatory, antitussive and chemoprotective as well as converter of rumen microbial fermentation and depression of methane resurrection (Hashemipour et al., 2013 and Bravo et al., 2014). The molecule of carvacrol has pivotal bioactivities on animal and poultry metabolism and physiology (Reiner et al., 2009), when added this component (carvacrol) in the diet could have antioxidant activity on poultry meat. Carvacrol does an important function as indigenous antioxidant from through depression of lipid peroxidation that leading to oxidative annihilation of cellular membranes (Yanishlieva et al., 1999). Furthermore, the harmful impacts of these components may produce to excess in the preparation of toxic metabolites (free radicals) and likewise to apoptosis. Many studies showed that extension by several phytogenic additives or their outputs like cold pressed oil, essential oil and extracts in poultry and animal feeds led to increasing live body weight, body weight gain, feed efficiency ratio, immune response, antioxidant status, carcass characteristics and goodness, with lowered morbidity and mortality averages (Alagawany et al., 2015 and Dhama et al., 2015). The supposition was that effective compounds of MP may act as growth stimulus in broiler production. The objective of the present study was to estimate MP supplementation to broiler diets on performance, physiological parameters, antioxidant enzyme activity (glutathione peroxidase) and lipid profiles.

\section{MATERIALS AND METHODS}

The experimental work of the present study was carried out at commercial farm, Al - Barqouqi Farm, Sinoris, Fayoum, Egypt to evaluate marjoram powder as a feed additive in Cobb broiler chick's performance.

A total number of 180 one day-old unsexed Cobb broiler chicks were used in this experiment. Chicks were randomly divided into five groups, each group had three replicates with 12 chicks each. Chicks were individually weighed and placed in electrically heated battery till the end of experiment. The first group fed on basal control diet without any additives, while, the rest fed on basal control diet with 1.0, 1.5, 2.0 and $2.5 \% \mathrm{MP}$, respectively. The chicks of each fold were assigned in a cage with slatted floor of iron.

The experimental period was divided into two feeding phases, starter and grower and finisher diets from 1-21 days of age from 22-38 days of age. The control diet had 23.39 and $21.62 \%$ crude protein and 3085.05 and $3231.38 \mathrm{Kcal} \mathrm{ME} / \mathrm{kg}$ diet for the starter and grower and finisher diets, respectively (Table 1).

Chicks have full access to feed and water during the experimental period. Artificial light was applied to maintain nearly $23 \mathrm{hrs}$ light per day during the experimental period. The environmental temperature was about $33^{\circ} \mathrm{C}$ during the first week old and it was gradually reduced by about $2{ }^{\circ} \mathrm{C}$ weekly until about $24-26^{\circ} \mathrm{C}$ at the fourth week up to the end of experiment ( 38 days of age).

Chicks were vaccinated against Newcastle disease three times, firstly with Hitchner B1 on the 7th day of age and twice with Lasota strain in drinking water at 12 and 24 days of age. At 14 and 28 days of age, 
Egyptian J. Nutrition and Feeds (2019)

Table 1 
chicks were vaccinated against infectious bursal disease (Gumboro). Live body weight and feed intake (FI) were recorded at 21 and 38 days of age for each replicate. Daily body weight gain and feed conversion ratio (feed:gain) were calculated for each replicate within each period.

Individual 30 blood samples were collected in dry clean centrifuge tubes at slaughter and serum was separated by centrifugation at $3000 \mathrm{rpm}$ for 15 minutes and assigned for subsequent determination. Quantitative determinations were done for the following: total cholesterol (Chol), high density lipoproteins (HDL), low density lipoproteins (LDL) and triglycerides (Trig), Aspartate aminotransferase (AST) and Alanine aminotransferase (ALT). All blood biochemical parameters were calorimetrically determined using commercial diagnosing kits (produced by Spectrum Diagnostics Company, Egypt). The glutathione peroxidase (GPx, EC 1.11.1.9) was calorimetrically determined according to Paglia and Valentine (1967). The white blood cells (WBCs) and red blood cells (RBCs) counts were determined by an improved Neubauer hemocytometer method (Jain, 1986). The hemoglobin (Hb) value was measured by colorimetric cyanomethemoglobin methods (Baker and Silverton, 1985). Serum total protein and albumin were determined according to Doumas (1971) and Witt and Trendelenburg (1982). Globulin concentration was calculated as the difference between total protein and albumin and then the ratio of albumin/ globulin was also calculated.

Data of studied traits were subjected to a one-way analysis of variance with treatment as a fixed main effect as follows: $Y_{i j}=\mu+T_{i}+e_{i j}$, where: $Y_{i j}=$ observed value in the $i^{\text {th }}$ treatment, $\mu=$ overall mean $T_{i}$ : treatment effect (i: 1 to 5) and $\mathrm{e}_{\mathrm{ij}}=$ random error term using General Linear Models (GLM) procedure of SPSS (2013). Means were compared for treatment effect when significant F values were obtained by Duncan's new multiple range test (Duncan, 1955).

\section{RESULTS AND DISCUSSIONS}

Effects of the dietary oregano powder supplementation on growth performance of broilers at different growth periods are presented in Table (2). Data showed that chicks fed $1.5 \%$ of MP was significantly $(\mathrm{P} \leq 0.05)$ heavier in body weight at 21 and 38 days of age than the control and other treated groups, recording the heaviest body weight (1016.389 and 2326.806) at 21 and 38 days of age respectively, followed by $1 \% \mathrm{MP}$ and the lower groups were $2.5 \%$ and $2.0 \% \mathrm{MP}$ at 21 and 38 days of age respectively. Before powwowing the growth performance outcomes of this study further, it would be useful to contemplate how phytogenic origins, such as marjoram or oregano, action as a growth stimulus in rapprochement to antibiotics. The mechanism of how antibiotics promote animal and poultry growth performance is fundamentally founded on a hypothesis from the outcomes of germ-free animal trials that antibiotics influence the microbiota in animal intestine (Niewold, 2007). However, this type of demonstration does not appear adequate in order to antibiotics are hired in a faint and sub-therapeutic potion in cattle and poultry, which extremely vary their intestine microbiota. Another potential explanation is that antibiotics normally accumulate in inflammatory cells, and most accumulated antibiotics enhance the intracellular killing of bacteria and attenuate the inflammatory response, thus influence animal production (Niewold, 2007). Moreover, many supposition to clarify the influence of antibiotics as growth promoters back to improving the nutrient sucking the intestinal wall of treated animal which is thinner in intestinal villi and total gut wall (Dibner and Richards, 2005). With regard to natural phytogenic sources, the technique for playing as a growth stimulus has not post been completely inspected, however from prior treatises (Hashemi and Davoodi, 2010) the growth promoting effect of phytogenic sources is probably due to its antimicrobial activity. The way by which oregano extract had antimicrobial influence in vitro was previously inspected and communicated (Krishan and Narang, 2014). Moreover, many previous studies indicated that oregano extract or oregano powder (OP) can play as a natural antioxidant, thus it would be also important and interesting to investigate the interaction between the growth and systemic ant oxidative defense property by the OP supplementation. The current results are agree with Ezz El-Arab (2008) and Mona Osman et al. (2010) who noted that, chicks fed either rosemary, marjoram or sweet basil containing basal diets at the upper level $(1 \mathrm{~g} / \mathrm{kg})$ at 28 and 42 days of age had a higher body weight means than those received the lower level of $0.5 \mathrm{~g} / \mathrm{kg}$. Also, treatment of marjoram $(1 \mathrm{~g} / \mathrm{kg})$ supplementation during growth periods of 42 days old gave the best score when compared with the corresponding treatments by an increment of $14.88,5.23$ and $2.42 \%$ over those of the control, rosemary and sweet basil, respectively. Kirkpinar et al. (2011) obtained only effects on BW at 7, 14, 21, 28 and 42 days. Brenes and Roura (2010) specified several techniques of the oregano essential oil (OEO) jobs that were classified into four groups: sensorial, antioxidant, antimicrobial and metabolic, where the gastrointestinal tract prepared for feed reception by oral sensing and after that encourages 
Egyptian J. Nutrition and Feeds (2019)

Table 2 
digestive secretions (saliva, salivary amylase, lipase, amylase and proteases) and gut motility. Adding mexican oregano oils in the diets could have participated results acquired in the performance of chicks. Also, in the same trend Ali (2014) found that appending the broiler diets with powder of marjoram leaves had significant $(\mathrm{P} \leq 0.05)$ effect on body weight at 21 and 42 days of age being the heaviest in the supplemented groups with 1 and $1.5 \%$ marjoram and lowest one was the control group even from supplemented group with $0.5 \%$ marjoram and the same results found by Silva Vazquez et al. (2015) in broilers treated by various kinds and levels from mexican oregano oil.

Likewise, some studies in broilers showed improvement in performance by adding OEO in chicks diets (Alali et al., 2013; El-Ghany and Ismail, 2013 and Kuçukyilmaz et al., 2014). The main effect of OEO on growth encouraging is coming from the content of carvacrol and thymol, as these ingredients may catalyze appetite and increase the efficiency of digestive enzymes and imbibition of nutrients (Roofchaee et al., 2011). Additionally, Sugiharto (2016) showed that the techniques of work of oregano oils on the grown accomplishment of chickens are refinements in the taste and palatability of the food and the bearable refinements in feed consumption and execution of chickens; encouragement of the reproduction and growth of absorptive cells in the gastrointestinal tract (resulting in greater villus height and deeper crypt); and effects on the production and/or activity of the digestive enzymes, e.g., enhanced activities of amylase and protease. Likewise, Song Ri et al. (2017) reported that adding oregano powder in diets raised average daily body gain through the growing and the whole period. But, many studies showed that there was no impact of oregano and/or its components on chick growth (Barreto et al., 2008; Avila-Ramos et al., 2012 and Kirkpinar et al., 2014). Moreover, some previous research indicated that there was no positive effect on growth performance at any concentrations of oregano (Karimi et al., 2010).

Effects of the dietary oregano powder supplementation on feed intake and feed conversion ratio during the periods from 0 to 21, 22 to 38 and 0 to 38 days of age are showed in Table (3). Results showed that adding marjoram leaves powder in broiler diets had significant effects on feed intake and feed conversion during all periods studied. Treated groups achieved the lowest $(\mathrm{P} \leq 0.05)$ FI as compared with control group especially groups treated by $2.5 \% \mathrm{MP}$. Also, supplementing the broiler diet with oregano leaves powder improved $(\mathrm{P} \leq 0.05)$ feed conversion ratio during the all periods studied, except, the period from 0 to 21 days of age as compared with the control group. But, feeding with $1.5 \%$ marjoram gave the best value of feed conversion ratio during all periods compared with the control and other treatments. These results in the same trend with Ezz El-Arab (2008) and Mona Osman et al. (2010) who detected that broilers received basal diet with either levels of rosemary, $0.5 \mathrm{~g} / \mathrm{kg}$ of marjoram or sweet basil supplementation consumed the lowest $(\mathrm{P} \leq 0.05)$ amounts than the control group. Also, these results confirmed by Ali (2014) who found the same results in broilers treated by marjoram leaves powder at 0.5 , 1.0 and $1.5 \%$ for feed consumption and feed conversion ratio especially, groups fed 1.0 and $1.5 \%$ marjoram. In contrast, Song Ri et al. (2017) showed that the supplementation of OP increased average daily FI during the grower period and tended to increase the average daily FI during the overall experiment period.

Silva Vazquez et al. (2015) found that FI increased with low levels from Mexican oregano oil and decreased with high levels, the lower FI with Mexican oregano oil MOO at the highest concentration may suggest adverse effects due to OEO component toxicity. Dusan et al. (2006) indicated that carvacrol (the affect material in oregano) at 55\% can causes cytotoxic effects in chickens and therefore lowering in FI.

Kirkpinar et al. (2011) reported that betterments in broiler feed efficiency with extension of 150 and $300 \mathrm{ppm}$ of OEO in the food result from improvement the performance of the chickens, because of the growth promoting effect of the oil levels in the diet and the age of the chickens. Conflicting results were found in other study (Cross et al., 2007), which reported that supplementation of 100, 150, and 1,000 ppm of OEO in chicken diets did not have any effect on their production performance. Also, Symeon et al. (2010) concluded that the supplementation of broiler feed with OEO had significant negative effects on the feeding and drinking behavior as well as on the activity of these broilers. In addition, Cross et al. (2007) reported that phenolic terpenes give a flavor to the diet and it can be unpleasant to chickens during the first weeks.

Marjoram powder is a rich source of medicinal components and many biologically active substances, including phenolic acids and flavonoids, which have various physiological and biochemical functions in the body. As seen in Table (4), levels of dietary marjoram significantly affected the serum concentrations of total protein, albumin alanine aminotransferase (AST) and aspartate aminotransferase (ALT) in broiler chicks. Specifically, supplementation of marjoram led to increases in total protein and albumin, while, level of globulin and A/G ratio was not affected. Liver enzymes (AST and ALT) were significantly decreased with supplementation of marjoram in broiler diets. In this respect, Abd El-Ghany and El- 
Egyptian J. Nutrition and Feeds (2019)

Table 3 
Abdel-Wahab

Table 4 
Egyptian J. Nutrition and Feeds (2019)

Table 5 
Metwally, 2010 reported that active compounds in marjoram could protect liver damage and thus reducing the activity of liver enzymes. The positive effect on liver function may be attributed to the pharmacological activity of marjoram. Demir et al. (2005) reported that the marjoram powder $(1 \mathrm{~g} / \mathrm{kg}) \mathrm{in}$ boiler feed increases total serum protein.

Effects of marjoram on hemoglobin (Hb), red blood cells (RBCs) and white blood cells (WBCs) of the broiler chickens are summarized in Table (4). The inclusion of $2.5 \%$ marjoram had higher Hb values $(\mathrm{P}=$ 0.022) than the control group. Also, using MP at level of $2 \%$ increased RBCs of broiler compared with the control. All levels of MP used in this study increased WBCs compared with the control. The addition of MP showed superiority significant effect RBCs and WBCs as compared with the control (Areaaer, 2016), this may be due to marjoram is an excellent source of iron being $82.71 \mathrm{mg} / 100 \mathrm{~g}$ (Al Garni and Hafez, 2015), as an essential nutrient for the production of red blood cells. The increase in WBCs in the marjoram-treated group may be due to that thymol present in marjoram may enhanced immune system justifying better immune responses (Shad et al., 2016).

As shown in Table (5), the serum contents of triglyceride, cholesterol and LDL were significantly decreased, but HDL level was increased in serum of broiler fed diets containing marjoram compared with those of the control group. Carvacrol and thymol present in the marjoram have a cholesterol lowering property by inhibiting hepatic 3-hydrox-3-methylglutaryl coenzyme a reductase, which is a cholesterol synthesis enzyme (Mazmanoglu, 2008). Shad et al. (2016) stated that carvacrol and thymol supplementation decreased $(\mathrm{P} \leq 0.05)$ serum cholesterol level. Also, significant decreases in serum triglyceride level were found in birds fed $10 \mathrm{mg}$ marjoram $/ \mathrm{kg}$ diet (Abou-Elkhair et al., 2014). The reduction in plasma lipids by marjoram addition may explain the increase in the antioxidant capacity of the birds fed those diets.

Antioxidant enzymes such as GSH-Px are the first line defense antioxidants (Ray and Husain, 2002). Also, in Table (5), GSH-Px activity in the serum of marjoram-treated groups was significantly increased $(\mathrm{P} \leq 0.001)$ by approximately $2.9-6.4 \%$ in comparison with the control. Marjoram has been reported to produce strong antioxidant activities (Badee et al., 2013), may due to its have carvacrol molecule that plays an important role as a natural antioxidant in the decline of lipid peroxidation, resulting in oxidative destruction of cellular membranes (Rhee et al., 1996 and Yanishlieva et al., 1999). As a result, the higher concentrations of GSH-Px, due to the addition of marjoram, may provide a more efficient scavenging of free reactive radicals in broilers.

\section{CONCLUSION}

Considering the results of the current study it could be concluded that supplementation of MP, particularly $1.5 \%$ level can improve productive, physiological parameters, antioxidant enzyme activity (glutathione peroxidase), lipid profiles and also as an alternative growth promoter for Cobb broiler chicks.

\section{REFERENCES}

Abdel-Daim M.M., M.A. Abd Eldaim and M.M. Mahmoud (2014). Trigonella foenum-graecum protection against deltamethrin-induced toxic effects on hematological, biochemical, and oxidative stress parameters in rats. Can. J. Physiol. Pharmacol. 92 (8): 679-685.

Abd EI-Ghany, M.A. and N.Y. El-Metwally (2010). Effect of marjoram leaves on injured liver in experimental rats. Report and Opinion 2(12):181-191.

Abou-Elkhair, R., K. M. Gaafar and N. M. Elbahy (2014). Bioactive effect of dietary supplementation with essential oils blend of oregano, thyme and garlic oils on performance of broilers infected with eimeria species. Global Veterinaria. 13(6):977-985.

Adil, S., T. Banday, G. Ahmad Bhat, M. Salahuddin, M. Raquib and S. Shanaz (2011). Response of broiler chicken to dietary supplementation of organic acids. J. of Central European Agriculture. 12: 498-508. 
Alagawany M.M., M.R. Farag, K. Dhama, M.E. Abd El-Hack, R. Tiwari, G.M. Alam (2015). Mechanisms and beneficial applications of resveratrol as feed additive in animal and poultry nutrition: A Review. Int. J. Pharmacol. 11: 213-221.

Alali, W. Q., C. L. Hofacre, G. F. Mathis and G. Faltys (2013). Effect of essential oil compound on shedding and colonization of Salmonella enterica serovar Heidelberg in broilers. Poultry Science 92: 836-841.

AL Garni, E.H. and D.A. Hafez (2015). Effect of extracts of some herbs on fertility of male diabetic rats. J. of American Sci., 11(11).

Ali, A. H. H. (2014). Productive performance and immune response of broiler chicks as affected by dietary marjoram leaves powder. Egypt. Poult. Sci. Vol. (34): 57-70.

Areaaer, A. H. J. (2016). Effect of addition different of oil marjoram (Origanum Majorana) oil in the diet on productive performance, immune responses and some blood parameters in broiler chickens. Kufa J. for Agri. Sci., 8(4): 151-165.

Avila-Ramos F, A. Pro-Martinez, E. Sosa-Montes, J.M. Cuca-Garcia, C.M. Becerril-Perez, J.L. FigueroaVelasco and C. Narciso-Gaytan (2012). Effects of dietary oregano essential oil and vitamin E on the lipid oxidation stability of cooked chicken breast meat. Poult. Sci., 91: 505-511.

Badee, A.Z.M., R.K. Moawad, M.M.Elnoketi and M.M. Gouda (2013). Improving the quality and shelflife of refrigerated chicken meat by marjoram. J. of Appl Sci. Res. 9: 5718-5729.

Baker F.J. and R.E. Silverton (1985). Introduction to medical laboratory technology. Butterworths, Boston, UK.

Barreto M, J. Menten, A. Racanicci, P. Pereira and P. Rizzo (2008). Plant extracts used as growth promoters in broilers. Braz. J. Poult. Sci., 10:109-115.

Botsoglou, N.A., E. Christaki, P. Florou-Paneri, I. Gieannenas, G. Papageorgiou and A.B. Spais (2004). The effect of a mixture of herbal essential oils or $\alpha$-tocopheryl acetate on performance parameters and oxidation of body lipid in broilers. S. Afr. J. Anim. Sci., 34: 52-61.

Bravo D., V. Pirgozliev and S.P. Rose (2014). A mixture of carvacrol, cinnamaldehyde, and capsicum oleoresin improves energy utilization and growth performance of broiler chickens fed maize-based diet. J. of Anim. Sci., 92: 1531-1536.

Brenes, A. and E. Roura (2010). Essential oils in poultry nutrition: Main effects and modes of action. Anim. Feed Sci. and Technology 158:1-14.

Cross, D. E., R. M. McDevitt, K. Hillman and T. Acamovic (2007). The effect of herbs and their associated essential oils on performance, dietary digestibility and gut microflorainchickensfrom7 to 28 days of age. Br. Poult. Sci., 48: 496-506.

Demir E, Ş. Sarica, M.A. Ozcan and M. Suiçmez (2005). The use of natural feed addivites as alternative to an antibiotic growth promoter in broiler diets. Archiv für Geflügelkund; 69:110-116.

Dhama K, S. K. Latheef, M. Saminathan, H. Abdul Samad, K. Karthik, R. Tiwari, R.U. Khan, M. Alagawany, M.R. Farag, G.M. Alam, V. Laudadio and V. Tufarelli (2015). Multiple beneficial applications and modes of action of herbs in poultry health and production-A review. Int. J. Pharmacol, 11: 152-176.

Dibner, J.J. and J.D. Richards (2005). Antibiotic growth promoters in agriculture: history and mode of action. Poult. Sci., 84: 634-643.

Dorman, H. J. D. and S. G. Deans, (2000). Antimicrobial agents from plants: antimicrobial activity of plant volatile oils. J. of Appl. Microbiology. 88:308-316.

Doumas B., (1971). Colorimetric determination of serum albumin. Clin.Chem.Acta. 31: 400-403.

Duncan, D. B., (1955). Multiple ranges and multiple F- test. Biometric, 11: 10-42.

Dusan, F., M. Sabol, D. Katarína and B. Dobroslava (2006). Essential oils their antimicrobial activity against Escherichia coli and effect on intestinal cell viability. Toxicology Int. Vitro 20: 1435-1445.

El-Ghany, W. A. A. and M. Ismail (2013). Tackling of experimental colisepticaemia in broiler chickens using phytobiotic essential oils and antibiotic alone or in combination. Iranian J. of Vet. Res. 15:110115. 
Ezz El-Arab, W. F. (2008). Productive, physiological, immunological and economical effects of supplementing natural feed additives to broiler diets. M. Sc. Thesis Faculty of Agric., Alex. University, Egypt.

Ghazalah, A. A. and A. M. Ali (2008). Rosemary leaves as a dietary supplement for growth in broiler chickens. Int. J. of Poult. Sci., 7: 234-239.

Giannenas, I., P. Florou-Paneri, M. Papazahariadou, E. Christaki, N. A. Botsoglou and A. B. Spais (2003). Effect of dietary supplementation with oregano essential oil on performance of broilers after experimental infection with Eimeria tenella. Archives of Anim. Nut., 57(2): 99-106.

Hashemi, S.R. and H. Davoodi (2010). Phytogenics as new class of feed additive in poultry industry. J. Anim. Vet. Adv. 9: 2295-2304.

Hashemipour, H., H. Kermanshahi, A. Golian and T. Veldkamp (2013). Effect of thymol and carvacrol feed supplementation on performance, antioxidant enzyme activities, fatty acid composition, digestive enzyme activities, and immune response in broiler chickens. Poult. Sci., 92 (8): 2059-69.

Hernandez, F., J. Madrid, V. García, J. Orengo and M. D. Megías (2004). Influence of two plant extracts on broilers performance, digestibility and digestive organ size. Poult. Sci., 83:169-174.

Jain, M.C. (1986). Essential of Veterinary Hematology. WB. Saunders Co., Philadelphia.

Karimi, A., F. Yan, C. Coto, J.H. Park, Y. Min, C. Lu, J.A. Gidden, J.O. Lay and P.W. Waldroup (2010). Effects of level and source of oregano leaf in starter diets for broiler chicks. J. Appl. Poult. Res., 19: $137-145$.

Khan, R. U., S. Naz, Z. Nikousefat, V. Tufarelli and V. Laudadio (2012). Thymus vulgaris: alternative to antibiotics in poultry feed. World's Poult. Sci. J., 68: 401-408.

Kim, E., Y. Choi, J. Jang and T. Park (2013). Carvacrol protects against hepatic steatosis in mice fed a high-fat diet by enhancing SIRT1-AMPK signaling. Evidence-Based Complementary and Alternative Medicine, 1-10.

Kirkpinar, F., H.B. Ünlü, and G. Ozdemir (2011). Effects of oregano and garlic essential oils on performance, carcass, organ and blood characteristics and intestinal micro flora of broilers .Livestock Sci., 137: 219-225.

Kirkpinar, F., H.B. Ünlü, M. Serdaroğlu and G.Y. Turp (2014). Effects of dietary oregano and garlic essential oils on carcass characteristics, meat composition, colour, $\mathrm{pH}$ and sensory quality of broiler meat. Br. Poult. Sci., 55:157-166.

Krishan, G and A. Narang (2014). Use of essential oils in poultry nutrition: a new approach. J. Adv. Vet. Anim. Res., 1: 156-162.

Küçükyılmaz, K., M. Bozkurt, M. Çınar, A.U. Çatlı, E. Bintaş and R. Erkek (2014). The effects of an organic rearing system and dietary supplementation of an essential oil mixture on performance and meat yield of slow-growing broilers in two seasons. South African J. of Anim. Sci., 44: 360-370.

Lee, K. W., H. Everts and A. C. Beynen (2004). Essential oils in broiler nutrition. Int. J. Poult. Sci., 3: 738-752.

Leon-Rodriguez A de, P. Escalante-Minakata, M.I. Jimenez-Garcia, L.G. Ordo-ez-Acevedo, J.L. Flores Flores and R.A. Barba de la (2008). Characterization of volatile compounds from ethnic Agave alcoholic beverages by gas chromatography-mass spectrometry. Food Technol. Biot.. 46(4): 448-455.

Mathlouthi, N., T. Bouzaienne, I. Oueslati, F. Recoquillay, M. Hamdi, M. Urdaci and R. Bergaoui (2012). Use of rosemary, oregano, and a commercial blend of essential oils in broiler chickens: In vitro antimicrobial activities and effects on growth performance. J. Anim. Sci., 90 (3): 813-23.

Mazmanoglu, G. (2008). Effects of dietary antibiotic, essential oil mixture and organic acid supplementation; on performance, some organ weights and blood parameters in broilers [thesis]. Istanbul (TUR): İstanbul University, Institute of Health Science, Department of Animal Nutrition and Nutritional Diseases.

Mitsch, P., K. Zitterl-Eglseer, B. K“ohler, C. Gabler, R. Losa, and I. Zimpernik. (2004). The effect of two different blends of essential oil components on the proliferation of Clostridium perfringens in the intestine of broiler chickens. Poult. Sci., 83:669-675. 
Mona Osman, M., H.M. Yakout, H.F. Motawe and W.F. Ezz El-Arab (2010). Productive, physiological, immunological and economical effects of supplementing natural feed additives to broiler diets. Egypt. Poult. Sci. J., 30(1): 25-53.

National Research Council, N.R.C. (1994). Nutritient requirements of poultry. 9th ed. National Academy Press, Washington, DC.

Niewold, T.A. (2007). The nonantibiotic anti-Inflammatory effect of antimicrobial growth promoters, the real mode of action? A hypothesis. Poult Sci., 86: 605-609.

Paglia, D.E. and W.N. Valentine (1967). Studies on the quantitative and qualitative characterization of erythrocyte glutathione peroxidase. The J. of laboratory and clinical medicine, 70(1), 158-169.

Puvača, N., V. Stanaćev, M. Beuković, D. Ljubojević, L. Kostadinović and N. Džinić (2014). Effect of phytogenic feed additive (Allium sativum L.) in broiler chicken nutrition on breast meat quality and tissues cholesterol content. In 7th International Scientific/Professional Conference, Agriculture in Nature and Environment Protection, Vukovar, Croatia, 28th-30th May 2014 (pp. 75-80). Croatian Soil Tillage Research Organization (CROSTRO).

Ray, G. and S. A. Husain (2002). Oxidants, antioxidants and carcinogenesis. Indian J. Exp. Biol., 40:1213-1232.

Reiner, G.N., D.O. Labuckas and D.A. Garcia (2009). Lipophilicity of some GABAergic phenols and related compounds determined by HPLC and partition coefficients in different systems. J. Pharm. Biomed. Anal. 49: 686-691.

Rhee, K.S., L.M. Anderson and A.R. Sams (1996). Lipid peroxidation potential of beef, chicken and pork. J. Food Sci., 61: 8-12.

Roofchaee, A., M. Irani, M.A. Ebrahimzadeh and M.R. Akbari (2011). Effect of dietary oregano (Origanum vulgare L.) essential oil on growth performance, cecal microflora and serum antioxidant activity of broiler chickens. African J. of Biot. 10: 6177-6183.

Roth, F. and X. Kirchgessner (1998). Organic acids as feed additives for young pigs: Nutritional and gastrointestinal effects. J. of Anim. Feed Sci., 8: 25-33.

Shad, A. A., J. Bakht, H. U. Shah and Y. Hayat (2016). Antioxidant activity and nutritional assessment of under-utilized medicinal plants. Pak. J. Pharm. Sci, 29(6), 2039-2045.

Silva Vázquez, R., L.A. Durán Meléndez,, E.S. Estrada, C.R. Muela, G.V. Villalobos, G.M. Zamora and M.E. Hume, (2015). Performance of broiler chickens supplemented with Mexican oregano oil (Lippia berlandieri Schauer). R. Bras. Zootec., 44(8):283-289.

Song Ri, C., X.R. Jiang, M. Ho Kim, J. Wang, H.J. Zhang, S.G. Wu, V. Bontempo and G.H. Qi (2017). Effects of dietary oregano powder supplementation on the growth performance, antioxidant status and meat quality of broiler chicks. Italian J. of Anim. Sci., 16, (2): 246-252.

SPSS, (2013). IBM SPSS Statistics for Windows, Version 22.0. Armonk, NY: IBM Corp. Released, 2013.

Stanaćev, V., D. Glamočić, N. Milošević, N. Puvača, V. Stanaćev and N. Plavša (2011). Effect of garlic (Allium sativum L.) in fattening chick's nutrition. African J of Agric. Res., 6: 943-948.

Sugiharto, S. (2016). Role of nutraceuticals in gut health and growth performance of poultry. J. of the Saudi Society of Agric. Sci., 15(2): 99-111.

Symeon, G.K., C. Zintilas, N. Demitris, L.A. Bizelis and S.G. Deligeorgis (2010). Effect of oregano essential oil dietary supplementation on the feeding and drinking behavior as well as the activity of broilers. Int. J. of Poult. Sci., 9: 401-405.

Windisch, W., K. Shedle and A. Kroismayr (2008). Use of phytogenic products as feed additives for swine and poultry. J. of Anim. Sci., 86: 140-148.

Witt, L. and C. Trendelenburg (1982). A method for rapid determination of total protein of serum, J. P. Clin., Biochem., 220-235.

Yanishlieva, N.V., E.M. Marinova, M.H. Gordon and V.G. Raneva (1999). Antioxidant activity and mechanism of action of thymol and carvacrol in two lipid systems. Food Chem., 64: 59 - 66. 
Zhang, K.Y.; F. Yan, C.A. Keen and P.W. Waldroup (2005). Evaluation of microencapsulated essential oils and organic acids in diets for broiler chickens. Int. J. of Poult. Sci., 4: 612-619.

تأثير إضافة مسحوق البردقوش إلى علائق كتاكيث التسمين على الأداء الإنتاجي، ومكونات الام ونشاط انزيم مضاد الأكسدة.

\author{
عبدالوهاب عبدالله عبدالوهاب \\ كليه الزراعه جامعة الفيوم قسم انتاج اللواجن
}

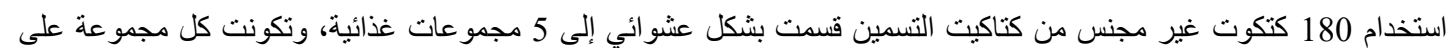

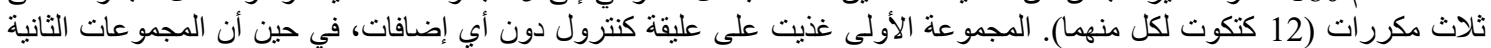

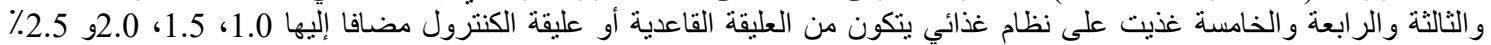

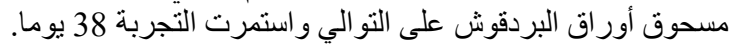

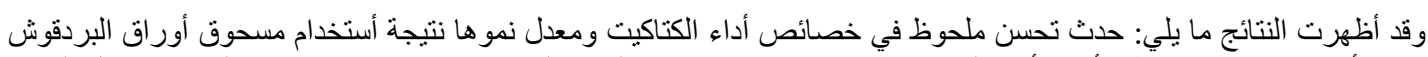

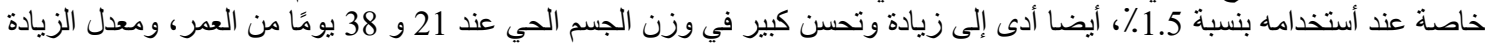

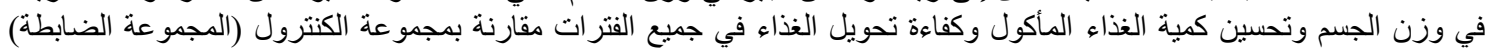

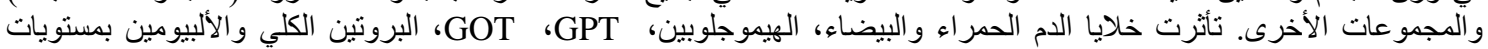

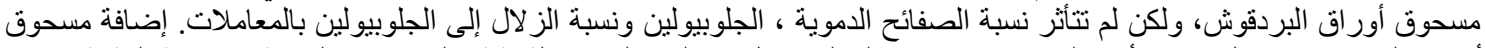

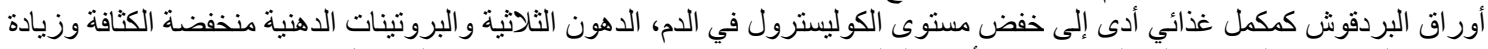

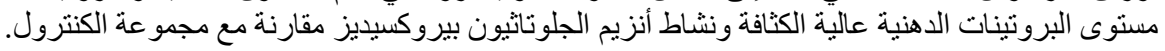

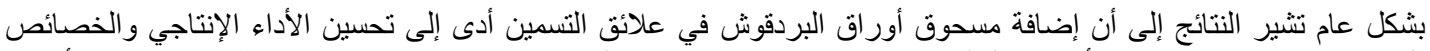

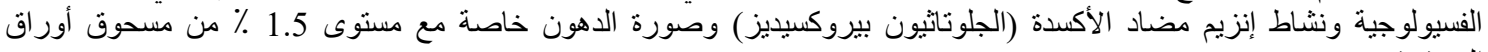
البردقوش. 